<症例報告 $>$

多発性囊胞性病変を呈した肝硬変非合併肝細胞癌の 1 例

\begin{tabular}{|c|c|c|c|c|c|c|c|}
\hline 水野 & 恭嗣 ${ }^{1)}$ & 野ツ & 和夫 ${ }^{1)}$ & 古沢 & 明彦1) & 元雄 & 良治1) \\
\hline 平井 & 信行 ${ }^{1)}$ & 松井 & 修2) & 泉 & 良平 ${ }^{3)}$ & 野田 & 八嗣4) \\
\hline & 雅志 ${ }^{1)}$ & 田中 & 延善1) & 小林 & 健一 ${ }^{1)}$ & 服部 & 信 \\
\hline 中沿 & 安二5) & & & & & & \\
\hline
\end{tabular}

要 旨：画像診断にて䨳胞性肝腫瘍が疑われ, 開腹生検にて確診し, 肝動脈塞栓療法 (TAE) および化学療法が奏効した多発性豪胞性病変を呈した肝硬変非合併肝細胞癌の 1 例を経験した ので報告する．症例は52歳の女性．主訴は腹部膨満感，身体所見では著明な肝腫大を認め，各 種画像診断から多発性裏胞性病変を伴う肝細胞癌が疑われ, 開腹生検を施行. 肝右葉全体を占 める巨大な塊状型の腫瘍で一部に亳胞性病変が認められ，肝左葉に数個の娘結節を認めた。肝 生検組織所見から非硬変肝に合併した肝細胞癌と診断した。 TAE，5-FU 持続動注，CDDP 動 注の併用による治療を行ったところ, 肝腫の縮小率は63.8\%で奏効度 PR を呈した. また, 画像 診断上も腫瘍および囊胞性病変の明らかな縮小を認めた。本例は多発性囊胞性病変を伴ら肝細 胞癌で, 肝硬変を合併していない点で特徽的であり，襄胞性病変の発生機序および治療効果を 検討する上で，興味深い症例と考学られた。

索引用語：多発性震胞性病変 肝細胞癌

はじめに

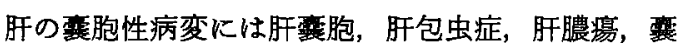
胞腺腫, 襄胞腺癌, 肝悪性腫湯の裏胞変性などがあげ られるが，これらの鑑別診断は，画像診断の進歩した 最近でも困難な場合が少なくない，また霬胞性となる 肝悪性腫啺としては，原発性および転移性のものがあ $\eta$, 転移性腫瘍に関しては胃癌, 胃平滑笳肉腫, 大腸 癌, 胆衰癌など数多くの報告がなされているい文．これ に対して，哓胞性となる原発性肝腫煌の中では，襄胞 性肝細胞癌の報告はきわめてまれで，本邦ではわずか に1例の報告があるだけである゙〉.さらに, 肝細胞癌で ありながら，他の豪胞性疾患としてとらえられ，肝細 胞癌の確診が困難な場合もある. 今回, 著者らは, 腹 部超音波検査, 腹部 CT などの画像診断にて襄胞性病 变を伴う肝腫湐を疑い，開腹生検にて確診し，肝動脈 塞栓療法（TAE）および化学療法による治療が奏効し

\footnotetext{
${ }^{1)}$ 金沢大学第 1 内科

${ }^{2)}$ 金沢大学放射線科

${ }^{3)}$ 金沢大学第 2 外科

4)富山労災病院内科

${ }^{5)}$ 金沢大学第 2 病理
}

た. 多発性栾胞性病変を呈した肝硬変非合併肝細胞癌 の 1 例を経験したので報告する。

\section{症例}

症例：52歳，女性，無職。

主訴：腹部膨满感。

家族歴：母，心疾患.

既往歴：20歳，胸膜炎，虫垂炎。

生活歴：輸血歷 ( $(-)$, 飲酒歷 ( $(-)$, 薬物歴 $(-)$.

現病歴：昭和60年 1 月頃より上腹部の膨満感を認め るよ5になり，6月 3 日富山労災病院を受診したとこ ろ, 腹部腫瘤を指摘され入院. 肝腫湟之診断され, 7 月17日精査加寮のため当科へ転院となった。

入院時現症：身長 $152.5 \mathrm{~cm}$, 体重 $49.5 \mathrm{~kg}$, 意識清明, 血压 $110 / 72 \mathrm{mmHg}$, 脈拍 $66 /$ 分, 整, 結膜に貧血, 黄疸 はなく，クモ状血管腫，手掌紅斑は認めなかった。胸 部では打聴診上異常なく，腹部では右季肋部から心窝 部にかけて膨隆し，肝を正中線上で $15 \mathrm{~cm}$, 右鎖骨中線 上で $11 \mathrm{~cm}$ 触知した。肝の性状は，辺縁鈍，表面平滑， 硬で，圧痛を認めた。脾腎は触知せず，腹水は認めな かった，右下腹部に手術瘦痕を認めた。下腿浮腫は認 めず，神経学的にも異常は認められなかった。

入院時検査成績 (Table 1)：血沈は $43 \mathrm{~mm} / \mathrm{hr}$ と中 
Table 1 Labo. Data on Admission.

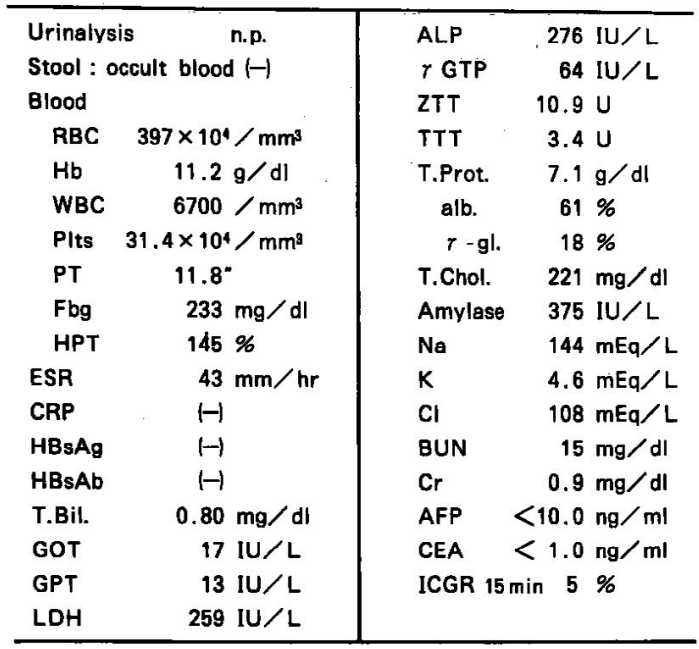

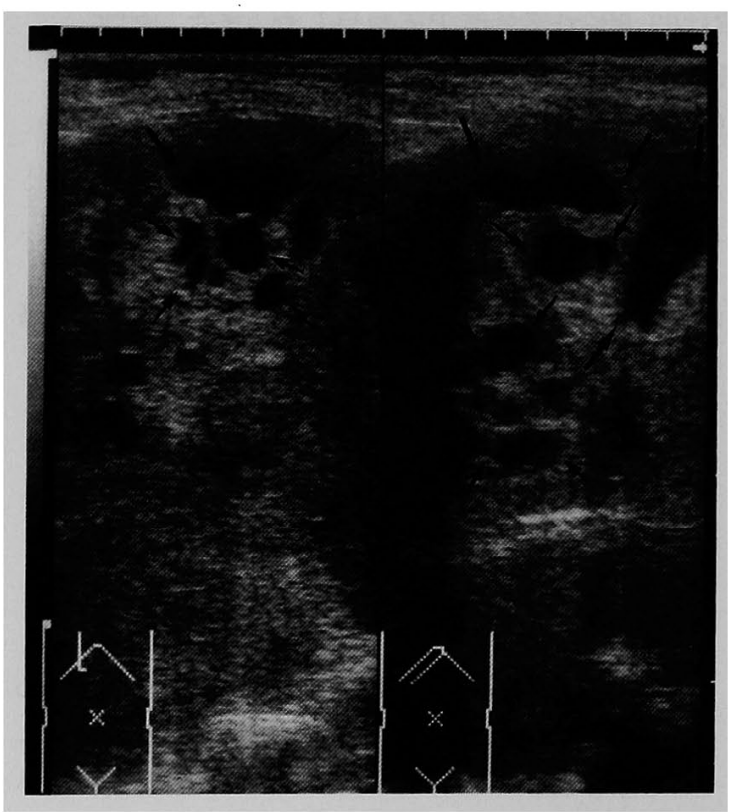

Fig. 1 Ultrasonography shows a huge echogenic area and multiple anechoic areas (arrows) with posterior echo enhancement in the right lobe of the liver.

等度に六進. 各種凝血学的検查, 生化学検查および肝 機能険查には異常は認められなかった. AFP, CEA， HBs 抗原, HBs 抗体はいずれも陰性であった。

各種画像診断所見：腹部超音波検査では，ほぼ肝右 葉全体にわたって径約 $10 \mathrm{~cm}$ の巨大な高エコー領域が 認められ，その内部には後部ェコーの増強を伴ら径約

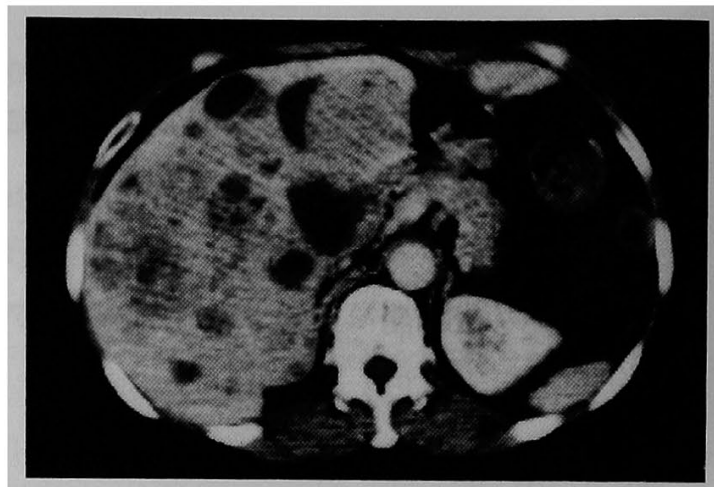

Fig. 2 CT scan shows low density areas associated with multiple lower density areas occupying the right lobe and medial segment of the left lobe of the liver.

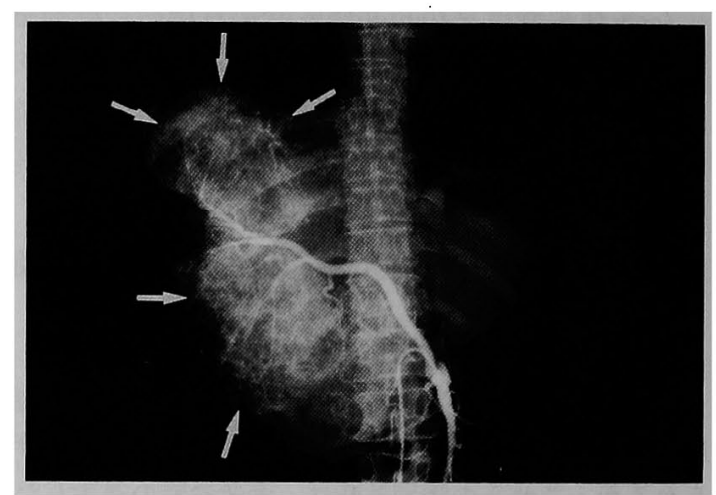

Fig. 3 Arterial phase of superior mesenteric arteriography shows the marked neovascularization in the anterior and posterior branches of the right hepatic artery (white arrows).

1〜6cm の境界明瞭な無エコー領域が多発性に認めら

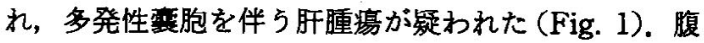
部 CTでは，肝右葉から左葉内側区域にかけて広範な 低吸収域が認められ，その内部に径約 $1 \sim 6 \mathrm{~cm}$ のさら にCT 值の低い低吸収域が多発性に認められた（Fig. 2). 選択的腹腔動脈造影動脈相では，左肝動脈上り分 岐する内側区動脈の末梢に径約 $2 \sim 3 \mathrm{~cm}$ の不整血管増 生を認めた. 上腸間膜動脈造影動脈相では, 右肝動脈 は上腸間膜動脈より分岐し，前後枝ともに著明な不整 血管増生を認めた (Fig. 3). 同造影毛細血管相では, 肝内に 2 個の巨大な腫湯濃染像を認め, 内部に多発性 の円形透亮像を認めた(Fig. 4). 以上の画像猃断上り, 多発性襄胞性病変を伴 5肝細胞癌が疑われ, 確定診断 のため 8 月24日（第39病日）開腹生検を行った。 


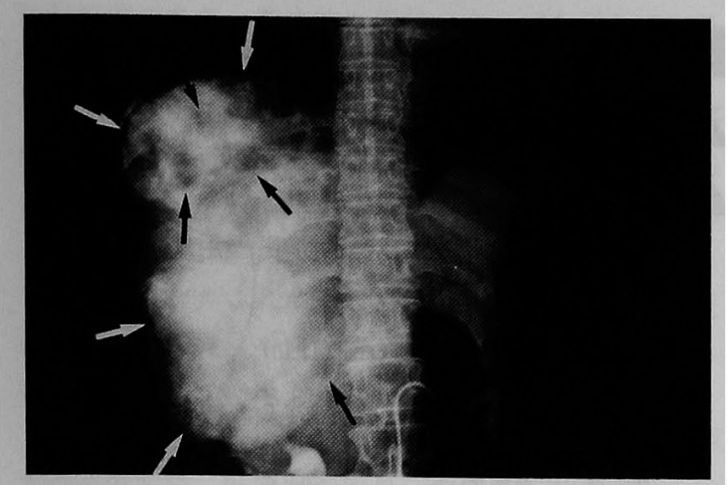

Fig. 4 Capillary phase of superior mesenteric arteriography shows two huge tumor stains (white arrows) with multiple round radiolucencies (black arrows) in the right lobe of the liver.
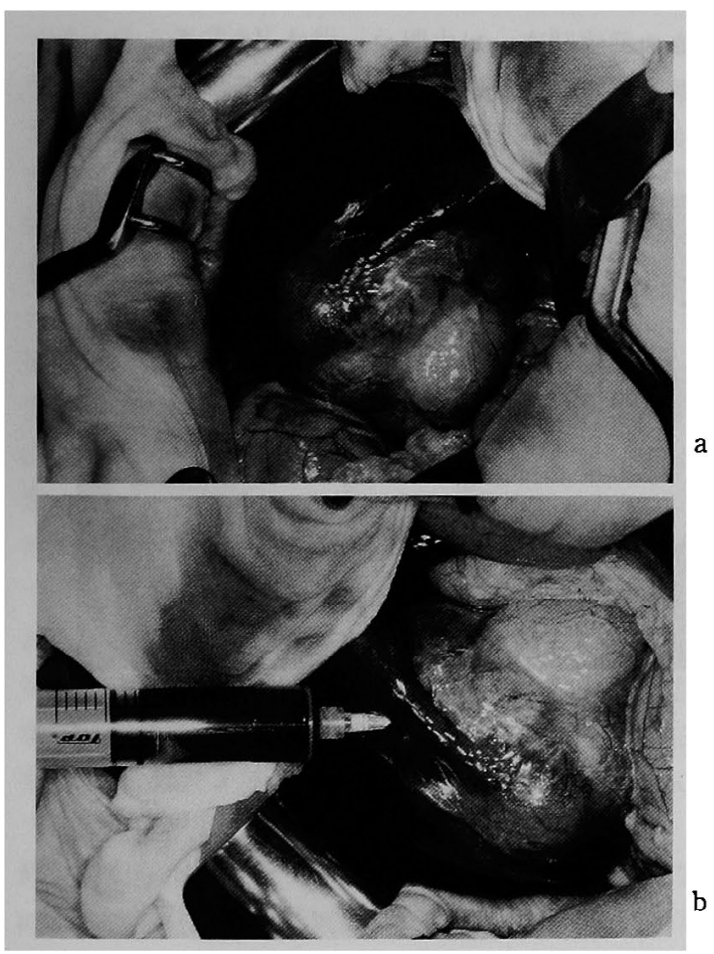

Fig. 5 a) Gross appearance of the tumor with multiple cystic lesions at laparotomy. b) Gross appearance of the content of the cystic lesions. Bloody serous fluid was obtained by aspiration.

手術所見：肝右葉全体に広がる灰白色の巨大な塊状 型の腫瘍が認められ，表面には一部雚胞性病変が認め

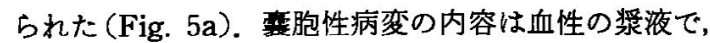
細胞診では class Iであった（Fig. 5b).

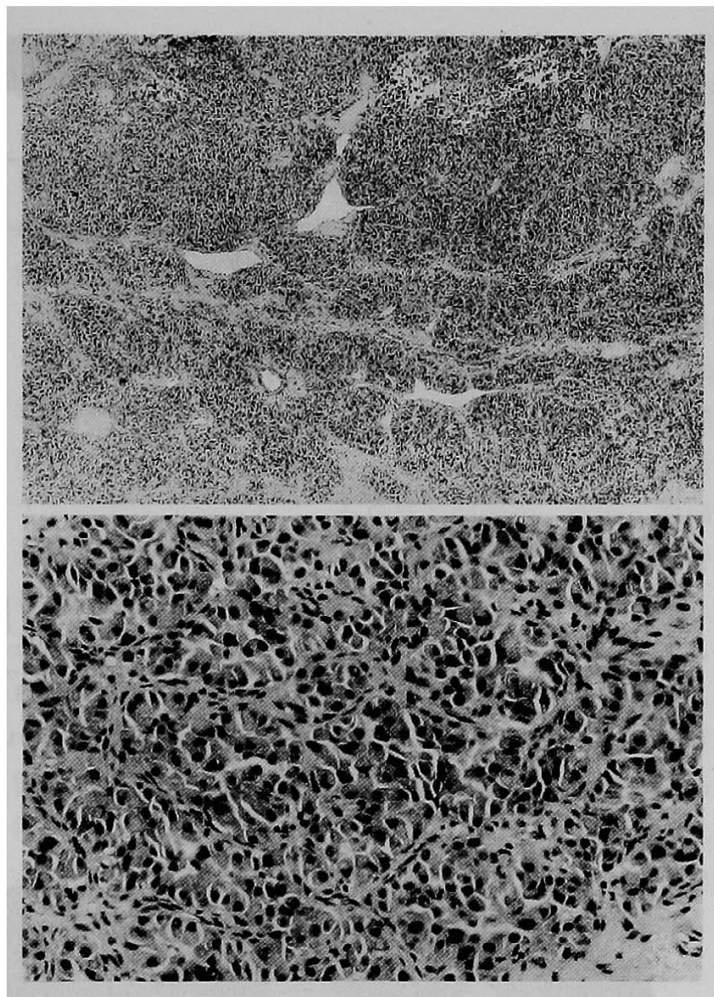

Fig. 6 Microscopic finding of the tumor. Tumor cells have eosinophilic granular cytoplasm. They are arranged in trabecular structures with sinusoidal lining (Edmondson's grade II III). Upper, HE., $\times 60$, and Lower, HE., $\times 165$

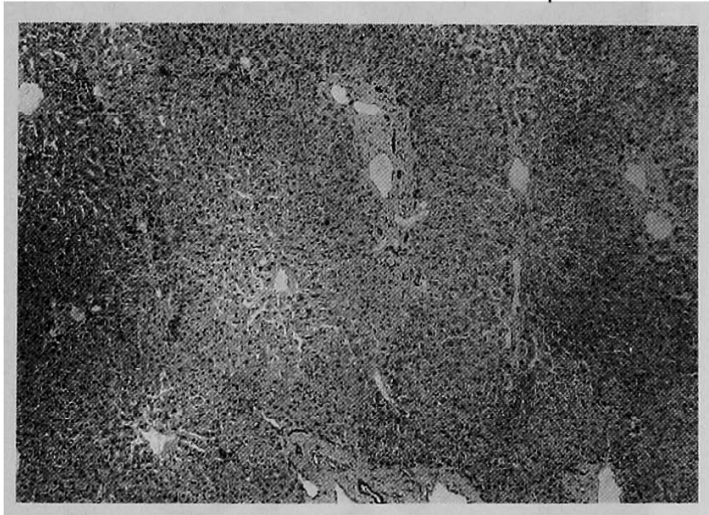

Fig. 7 Microscopic finding of the nontumorous part shows almost normal liver. Lobular architectures of the liver are preserved. Hepatocellular trabecles are not disturbed. $\mathrm{HE}$., $\times 60$

肝および腫瘍部生検所見：肝左葉内側区域に認めら れた娘結節より，径 $1 \mathrm{~cm}$ 大の生検を施行した。睡瘍は 
Abdominal fullness

Nausea

Vomiting

Hepatomegaly $(\mathrm{cm})$

(date) (7.17)

Reduction rate

of tumor (\%)

WBC

PIts. $\left(\times 10^{4}\right)$
6600

30.7

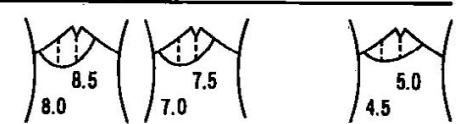

(10.18) (10.24)

(11.10)

30.8

42.0

63.8

82007500

3800

$42.5 \quad 44.4$

30.2
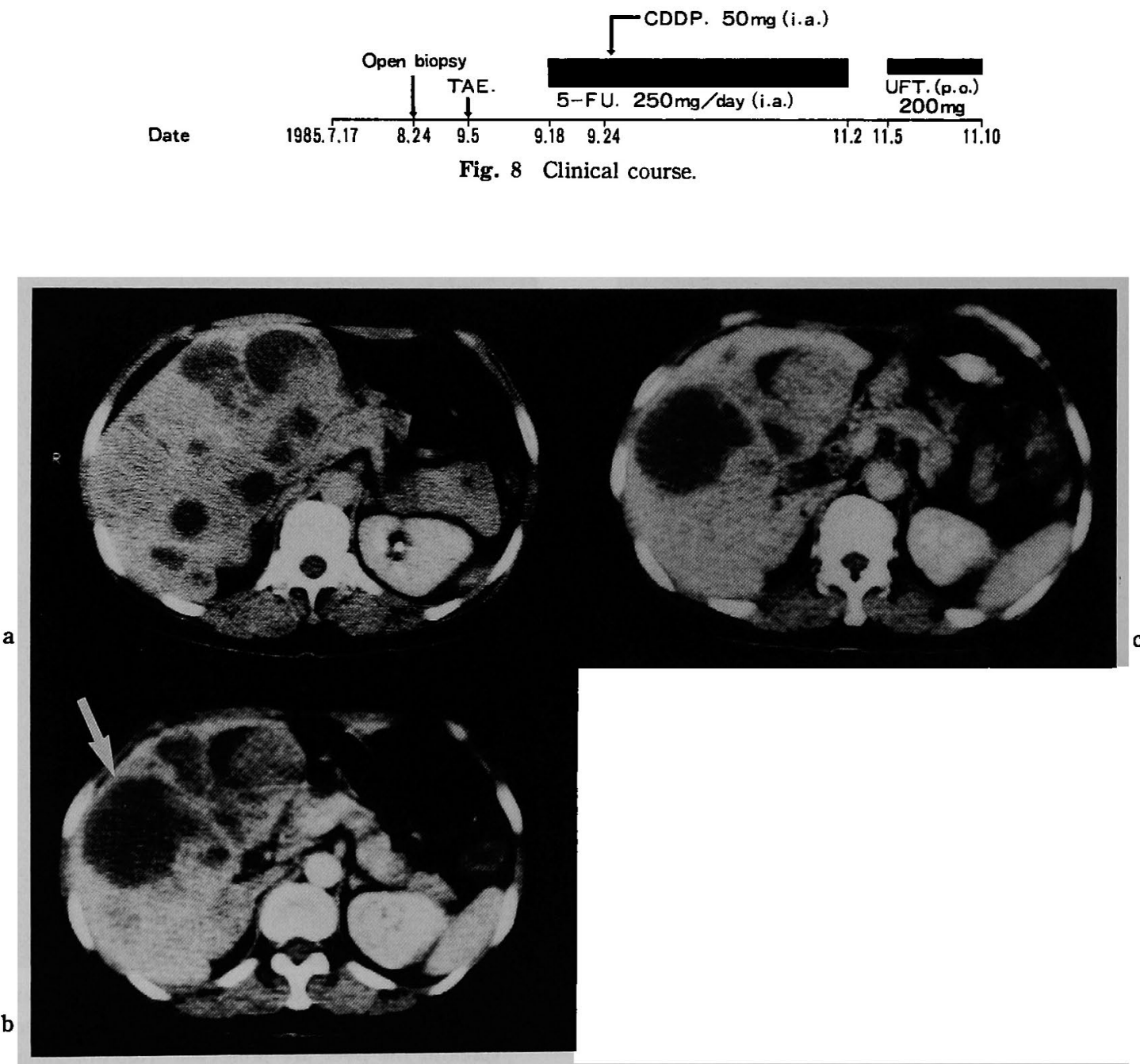

Fig. 9 CT scan shows the changes in size of the tumor during the hospital course. a) There is no change of the tumor as compared with that on admission (the 58th hospital day). b) Low density area indicating the necrosis of the tumor is visualized (white arrow) (the 85th hospital day). c) The decrease in size of the tumor and the cystic lesions is seen (the 109th hospital day). 
肝細胞癌であり，基本的に索状バターンを示している が, 類洞の抾張に乏しく，充実性の配列もみられ，所々 で周囲に線維組織を伴っていた (Fig. 6)。 また，畽瘍 細胞の胞体は好酸性であり，所々で為腺管形成をみる が，胆汁栓の形成は認められなかった (Fig. 6)。鍍銀 染色では，索状配列が明らかであり，線維形成が所々 で認められた．これに対して，非癌部肝組織はほぼ正 常であり，肝硬変中慢性肝炎はみられなかった（Fig. 7).

入院後経過：Fig. 8 に臨床経過を示した。な抬療 効果の判定は，肝腫触診所見，腹部 CT 所見 (Fig. 9) にて行った，本例では肝左葉に娘結節を認めたことか ら，手術適応はないと判断し，開腹生検時に左肝動脈 内に動注用チューブを留置し，9月5日（第51病日） にはコイルによる右肝動脈塞栓療法(TAE)を行った。 コイルによるTAEを行った理由は，右肝動脈の血流 を完全に遮断することにより，左肝動脈の血流を増加 させ，左肝動脈からの抗癌剤動注療法の奏効をはかる ためであった．9月12日（第58病日）の腹部 CT (Fig. 9a) では，入院時 (Fig，2）と比較して，まだ稙湯の大 きさに変化は認められなかった。 その後さらに 9 月 18 日（第64病日）からは，5-FU 250mg/日の持続動注を 開始し，9月24日（第70病日）には Cis-platinum (CDDP) 50mgをワンショット動注した。しかし, CDDP 動注により悪心呕吐などの消化器症状を強く 認めたため，以後は5-FU 持続動注のみ行った. 以上の 治療により，10月 9 日（第85病日)の腹部 CT(Fig. 9b) では腫場の壊死と考えられる低吸収域の出現が認めら れるよらになり，触診による肝腫の縮小率（癌化学療 法効果判定委員会「固形がん化学療法直接効果判定基 準」(1980)による)は10月24日（第100病日）では42\% を示した.11月 1 日(第108病日)に施行した動注チュー ブ造影にてチニーブの肝内逸脱が認められたため，持 続動注を中止し，11月 5 日（第112病日）ょりUFT 200 $\mathrm{mg} /$ 日の経口投与を開始したが, 11月 2 日(第109病日) の腹部 CT (Fig. 9c) では，腫瘍战よび要胞性病変と もに明らかな編小が認められた。ささらに, 11月10日（第 117病日）の肝腫の縮小率は63.8\%と著明な綟小を認 め，奏効度は PR(Partial Response)を示した。なお， 本例は昭和60年11月11日退院したが， 2 年 6 カ月経過 した現在も特に訴点なく外来通院中である。

\section{考察}

肝画像診断上, 豪胞性病変を呈する疾患として, 肝

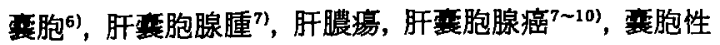

胆管癌 ${ }^{20)}$ ，血腫，票胞性過誤腫，肝包虫症 ${ }^{11)}$ ，転移性肝 腫湟 ${ }^{1-5)}$, 肝細胞癌(5よ゙があげられる. 近年, CT や超 音波などの画像猃断のめざましい進歩により，肝の腫 瘤性病変中衰胞性病変の診断率が向上しているが, 衰 胞性病変を呈する肝腫煬では，術前あるいは生前の診 断が困難であることも少なくなく，時として，切除標 本または剖検材料の検索によらなければならない場合 あみられる. 本症例です，各種画像診断から多発性襄 胞性病变を伴う肝細胞癌が疑われ，開腹生検にて肝細 胞癌の確定診断が下されている．また裹胞性病変を呈 する肝悪性腫場の中で, 転移性肝腫瘍が二次的に㘊胞 変性をきたした報告は，Wooten ら゙によれば300例中 12例 (4.0\%), Federle ら ${ }^{2)}$ によれば全体の $1 \sim 2 \%$, 品川ら 3 によれば48例中 7 例(14.6\%)，熊田ら 4 によれ ば67例中10例（14.9\%）とこれまでにかなり報告され ている。転移性肝腫湯に垔胞変性が多く認められる原 因として，腫瘍の発育速度が早く血液の供給が追いら けないこと，お上び化学療法の影響などが示㖫されて おり"，特に，転移性肉腫は転移性癌に比べて早期に壊 死・変性をきたしやすいとされている年, 。これに対し て，变胞変性をきたした肝細胞癌の報告はきわめてま れであり，これまで Ohtomo らうの 1 例報告があるに すぎない，Ohtomo ら ${ }^{5)}$ の報告では，亚胞形成の原因と して腫湯の壊死および出血を考えているが，一般に肝 細胞癌は，注とんど例外なく膨張性に発育し，腫慯の 増大と血流量の均衡が破綻することにより，中心部の 線維化を伴わす罣死に陥るため，時として要胞性にな るとされている，本症例でも，同様の機序により，重 瘍の壊死をきたし襄胞性病変が形成された可能性が推 測される.さらに, Ohtomo ら5)の報告では非癌部の肝 病变についての記載はないが，本症例では非癌部に明 らかな肝病変が認められなかったことが特徴的であ る. わが国では肝細胞癌の約 $90 \%$ に肝硬変を合併する といわれており ${ }^{22)}$ ，正常肝に肝細胞癌を合併すること は少ないとされている，肝硬変を合併しないことと， このよらな襄胞性病变の発生との間に何らかの関係が あるか否か，今後さらに症例の積み重齐が必要と思わ れる。

本例のような切除不能肝細胞癌に対する治療法とし て, 肝動脈結紮術, 門脈結愁術, 肝動脈塞栓療法 (TAE)，Ethanol 注入㞠法，抗癌剤動注療法，抗癌剂 全身投与などが娭討されているが，TA'Eの有効性に ついては次のような報告が指摘されている。すなわち， TAE の効果については，山田ら ${ }^{13,14}$ は 1 年生存率 $44 \%$ 
ときわめて有効であると報告しており，变胞性病変を 伴ら肝細胞癌に対しても，Ohtomoら帛によればきわ めて有効とされている．これに対して化学療法は，肝 切除術およびTAEなどの適応のない症例全例が対象 であり、これまでに, Adriamycin(ADM), Mitomycin $\mathrm{C}$ (MMC), 5-Fuoro-uracil (5-FU), Tegafur などの 投与が試みられている. Olweny ら ${ }^{15)}$ は ADM の有効 性を報告し，三浦ら ${ }^{16)} は 5-F U$ および MMC の有効性 を報告しているが，これまで総じて化学療法の有効率 は必ずしも高いとはいえないまた，最近新しい化学 療法として, Cis-platinum (CDDP), VP. 16 (Etoposide) などが試みられるようになり, Melia ら ${ }^{17.18)}$ 中田中ら ${ }^{19} に よ り$ 報告されているが，いずれる 有効率に飛躍的な進歩が認められないのが現状であ る. 本症例の治療についてみると、コイルによる TAE, CDDP 動注, 5-FU 持続動注など, TAE と化学 療法を併用し，触診に上る肝腫の縮小率は63.8\%で， 奏効度 PRであった. 一般にコイルによるTAEでは, ゼラチンスポンジによるTAEと比較して，血流が緩 徐に遮断されるため, 腫煌の広範な壊死は生じにくい とされて扣り，本症例では，TAEの効果に加兄て，化 学療法がさらに奏効した可能性が示唆された。 以上, 本症例は多発性变胞性病変を伴った肝細胞癌で, 肝硬 変を合併しない点で特徵的であり, 栾胞性病変の発生 機序および瘇湟に対する治療効果を検討する上で，興 味深い症例と考克られる。

\section{おわりに}

各種画像診断にて囊胞性肝腫湯が疑かれ，開腹生検 にて確診し，内科的治療が奏効した多発性竞胞性病変 を呈した肝細胞癌の 1 例を経験した。衰胞性病変の発 生機序扰よび肝細胞癌に対する治療効果を検討する上 で，興味深い症例と考え報告した。

なお本論文の要旨は，第21回日本肝臟学会西部会におい て発表した。

$$
\text { 文献 }
$$

1) Wooten WB, Green B, Goldstein HM: Ultrasonography of necrotic hepatic metastasis. Radiology 128 : 447-450, 1978

2) Federle MP, Filly RA, Moss AA: Cystic hepatic neoplasms: Complementary roles of CT and sonography. AJR 136 : 345-348, 1981

3）品川 孝, 大藤正雄, 木村邦夫, 他：肝細胞癌の超 音波診断。日消会誌 $78: 2402-2411 ， 1981$
4）熊田 卓, 中野哲, 綿引 元, 他：肝悪性腫瘍の 金胞变性について。柾超音波医学会講演論集 $40: 125-126,1982$

5) Ohtomo K, Furui S, Ilio M, et al : Multilocular cystic hepatocellular carcinoma. Radiation Medicine 2(3) : 164-166, 1984

6) Spiegel RM, King DL, Green WM: Ultrasonography of primary cysts of the liver. AJR 131: 235-238, 1978

7) Ishak KG, Wills GW, Cummins SD, et al: Billiary cystadenoma and cystadenocarcinoma : Report of 14 cases and review of the literature. Cancer 39 : 322-338, 1977

8) Yamasaki I, Tagata $K$, Hamamoto $Y$, et al: An autopsy case of mucinous cystadenocarcinoma of the liver. Yonago Acta Med 20: 142 $-146,1976$

9）岩崎 勇, 岩瀬裕鄉, 高橋 淳, 他：肝衰胞腺癌の 1 剖検例。肝䑏 $24: 1446-1450,1983$

10) Itai $Y$, Araki $T$, Furui $S$, et al: Computed tomography of primary intrahepatic biliary malignancy. Radiology $147:$ 485-490, 1983

11) Scherer U, Weinzierl $M$, Strum $R$, et al: Ciomputed tomography in hydatid disease of the liver: A report on 13 cases. J Comput Assist Tomogr 2: 612-617, 1978

12）元雄良治，小林健一，服部 信：肝㼨癌の診断体 系. 肝胆腈 $15(3): 321-326,1987$

13）在藤守男，山田龍作：旰癌の姑息的治療一動脈塞 栓療法(TAE). 肝胆膵 5(6)：1169-1175, 1982

14) Yamada $R$, Sato $M$, Kawabata $M$, et al: Hepatic artery embolization in 120 patients with unresenctable hepatoma. Radiology 148 : 397-401, 1983

15) Olweny CLM, Toya T, Katongole-Mbidde, et al: Treatment of hepatocellular carcinoma with adriamycin. Preliminary communication. Cancer $36: 1250-1257,1975$

16）三浦 健，和田達雄，灰田公彦，他：旰癌の姑息的 治療一抗癌剂動注療法. 肝胆膵 5(6): 1183 $-1188,1982$

17) Melia WM, Westaby $D$, Williams $R$, et al : Cis-Diamminodichloride platinum (cisplatinum) in the treatment of hepatocelullar carcinoma. Clin Oncol 7(4) : 275-280, 1981

18) Melia WM, Johnson PJ, Williams R, et al: 
Induction of remission in hepatocellular car-

cinoma. A comparison of VP 16 with

adriamycin. Cancer $51: 206-210,1983$
19）田中延善, 小林健一, 古沢明彦, 他：肝細胞癌に打 ける Etoposide 単独投与の効果について. 癌と化 学療法 14(8)：2583-2585, 1987

\title{
A case of multilocular cystic hepatocellular carcinoma without underlying cirrhosis
}

\author{
Yasutsugu Mizuno"1, Kazuo Notsumata ${ }^{11}$, Akihiko FurUSAwA ${ }^{11}$, Yoshiharu Motoo"1,

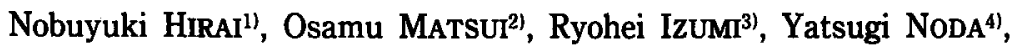 \\ Masashi UnOURA ${ }^{11}$, Nobuyoshi TANAKA ${ }^{11}$, Kenichi KoBAYASHI ${ }^{11}$, \\ Nobu HaTTORI ${ }^{l l}$ and Yasuni NAKanUMA ${ }^{5 !}$
}

A 52-year-old woman was admitted to our hospital because of marked hepatomegaly. The findings of Ultrasound, CT scan and Angiography suggested a hepatocellular carcinoma (HCC) associated with multiple cysts. The open biopsy was performed to confirm the diagnosis. A huge massive tumor about $10 \mathrm{~cm}$ in diameter partially associated with multiple cystic lesions was observed in the right lobe of liver at laparotomy. The histological finding of the tumor was $\mathrm{HCC}$, and the nontumorous part was almost normal liver.

TAE, intraarterial administration of 5-FU and CDDP, and oral administration of UFT were performed, resulting in the improvement of hepatomegaly (reduction rate: 63.8\%, partial response). The marked reduction of the tumor and cystic lesions was shown using CT scan. It is characteristic in this case that HCC developed in the normal liver and was associated with multiple cystic lesions. This case seems to be interesting from the viewpoint of the pathogenesis of multicystic HCC and the therapeutic effect of TAE and chemotherapy.

1) The First Department of Internal Medicine, School of Medicine, Kanazawa University (Kanazawa)

2) Department of Radiology, School of Medicine, Kanazawa University

3) The Second Department of Surgery, School of Medicine, Kanazawa University

4) Department of Internal Medicine, Toyama Rosai Hospital (Uozu)

5) The Second Department of Pathology, School of Medicine, Kanazawa University 